ÉKC Új Szent János Kórház és Szakrendelő, II. Belgyógyászat-Diabetológia, Budapest, ${ }^{1}$ Miskolci Egyetem, Egészségügyi Kar, Elméleti Egészségtudományi Intézet, Miskolc²

\title{
Nem-inzulintermészetü vércukorcsökkentők az 1-es típusú diabetes komplementer antidiabetikus kezelésében
}

\author{
Schandl László dr., ${ }^{(1)}$ Winkler Gábor dr. ${ }^{(1,2)}$
}

\begin{abstract}
Osszefoglalás
Az 1-es típusú diabetes vércukorcsökkentó kezelését - a remisszió szakaszát leszámitva - inzulin napszakos adagolása jelenti. Esetenként az anyagcsere-állapot javitása, a hypoglykaemia-gyakoriság vagy a vércukor-ingadozások csökkentése, az inzulinigény mérséklése, a súlycsökkenés elösegitése céljából, vagy más additiv elönyök szem elött tartásával az inzulinkezelés kiegészitéseként nem-inzulintermészetü vércukorcsökkentök hozzáadására is sor kerülhet. A közlemény áttekintie kombinációk elméleti hátterét, a korábbi, ma már jobbára orvostörténeti adatnak tekinthetó formáit, valamint napjainkban is szóba jövö lehetöségeit. Érinti a nálunk ez idő szerint nem forgalmazott hatóanyagokat is.

Kulcsszavak: 1-es típusú diabetes, inzulin, nem-inzulintermészetü vércukorcsökkentök, metformin, GLP-1receptoragonisták, SGLT-2-gátlók, pramlintid

\section{Non-insulin type antidiabetics in the complementer blood sugar lowering therapy in type 1 diabetes}

Summary: Antihyperglycaemic treatment of type 1 diabetes, with the exception of remission period, means daily administration of insulin. However, occasionally, it is beneficial to add non-insulin type antihyperglycaemics to insulin therapy, partly to improve the metabolic state, partly to lower the frequency of hypoglycaemic episodes, to decrease blood sugar fluctuations, to lower the insulin requirements, to help weight loss or to gain other additive benefits. The article reviews the theoretical background of these combinations, beginning with earlier forms - which are now mostly considered to be data of medical history - to the also nowadays possible options. The paper shortly turns on also to compounds that are not marketed at present in Hungary.

Keywords: type 1 diabetes, insulin, non-insulin type antidiabetics, metformin, GLP-1-receptor agonists, SGLT-2 inhibitors, pramlintide
\end{abstract}

DIABETOLOGIA HUNGARICA 28 (№5) 275-280. 2020. december

DOI: $10.24121 /$ dh. 2020.19

Rövidítések

NIADIAB: nem-inzulintermészetü antidiabetikum; NKA: normoglykaemiás ketoacidózis; SU: szulfanilurea

Közlésre érkezett: 2020. október 12. • Közlésre elfogadva: 2020. november 30.

A levelezésért felelős szerző: Prof. Dr. Winkler Gábor

ÉKC Új Szent János Kórház

1125 Budapest, Diós árok 1-3.

E-mail: gabor.winkler@janoskorhaz.hu 
A z 1-es típusú diabetes (T1DM) vércukorcsökkentő kezelése inzulin adagolásán alapul. Az ajánlások többsége leszögezi, hogy adása - a béta-sejt-kímélet szem előtt tartásával a szükséges és elégséges legkisebb dózisban, a remisszió idején is folytatandó. ${ }^{1} \mathrm{E}$ megállapításoknak nem mond ellent, hogy számos nem-inzulintermészetű antidiabetikum (NIADIAB) inzulin kiegészítéseként történő alkalmazására is sor került a korábbiakban e kórforma felnőttkori eseteiben, néhány készítmény törzskönyvi előiratában - vagy bizonyos feltételek teljesülése esetén törzskönyvön kívüli indikációval, off-label jelleggel - pedig napjainkban is szerepel. E kombinációk elméleti hátterét és jelen gyakorlatát tekinti át e közlemény.

Munkánk nem foglalkozik a napszakos inzulinkezelés formáival - intenzív-konzervatív inzulinterápia (ICT), inzulinpumpakezelés (CSII), napi többszöri inzulinadás (MDI) -, pusztán az inzulinadás és a nem-inzulintermészetű vércukorcsökkentők együttadásának kérdéskörét vizsgálja. Bár a szóba jövő készítmények, illetve készítménycsoportok egy része nálunk jelenleg nem forgalmazott, a teljesség kedvéért ezeket is érintjük.

\section{Nem-inzulintermészetü vércukorcsökkentők adásának lehetséges javallatai T1DM-ben}

Jól ismert, hogy a kívülről történő inzulinpótlás számos megoldatlan vagy nem teljesen megoldott problémával kísért szükséges kényszermegoldás, amely hiányosságain a korszerű inzulinkészítmények jelentősen enyhítettek ugyan, de teljesen kiküszöbölni még nem tudták. Ilyen a szoros anyagcserekontrollt kísérő fokozott hypoglykaemia-kockázat, az új készítmények adása mellett is megfigyelhető glykaemiás variabilitás, az inzulinok hatásgörbéje és az élettani inzulinszekréció dinamikai különbségei - ideértve az ultragyors prandiális inzulin farmakodinámiás jellemzőit is -, az állapotot kísérő relatív hyperglukagonaemia, valamint a kezelést kísérő gyakori súlygyarapodás és társuló kardiovaszkuláris kockázatfokozódás. ${ }^{2}$ Egy további gond - amint azt számos prospektív vizsgálat, ${ }^{3}$ valamint metaanalízis, network-elemzés ${ }^{4}$ is megerősítette -, hogy a T1DM-es betegek mintegy 80\%-a nincs a terápiás célértéken.

Szinte nincs olyan NIADIAB-csoport, amely adásával ne próbálkoztak volna T1DM-ben a felsoroltak ellensúlyozására vagy mérséklésére. Kiegészítő alkalmazásuk elméleti indokát képezhette a hyperglykaemia csökkentésén túl a hypoglykaemia mérséklése (minden készítménycsoport, amely lehetővé tette alacsonyabb inzulindózis alkalmazását), a posztprandiális (pp.) vércukor-emelkedések (akarbóz, pramlintid), valamint a napszakos vércukor-ingadozások mérséklése (szulfanilureák [SU-k], DPP-4-gátlók, GLP-1-receptoragonisták [RA-k]). Az inzulinérzékenység növelése (metformin, tiazolidindionok, GLP-1-RA-k), a testsúly csökkentése (metformin, SGLT-2-gátlók), az immunológiai folyamatok erősítése (tiazolidindionok), valamint az antioxidáns hatás erősítése (metformin). Napjainkban kapott kiemelt hangsúlyt a kardiorenális védelem (elsősorban az SGLT-2-gátlók esetében), s próbálkozások folynak a kórformára általában jellemző relatív hyperglukagonaemia eddigieknél - GLP-1-RA-k, DPP-4-gátlók - erőteljesebb visszaszorítására. 5,6,7

A felsoroltak egy része ma már csak történeti jelentőségű. E körbe tartoznak a SU-k és az inzulin együttes adásával kapcsolatos vizsgálatok. Egyes származékokkal - chlorpropamid, tolazamid, glibenclamid, glimepirid - folytatott in vitro megfigyelések alapján feltételezték ugyanis, hogy adásuk in vivo is javíthatja az inzulinérzékenységet, ezáltal csökkenthetik a kívánt anyagcsere-állapot elérését biztosító inzulinadagot. Az esetenként meglévő reziduális inzulinszekréció serkentésével mérsékelhették a pp. csúcs mértékét és a glykaemiás variabilitást. Bebizonyosodott azonban, hogy az inzulinhatás remélt fokozódása in vivo érdemben nem érvényesül, ugyanakkor a reziduális inzulinszekréció serkentése siettetheti az abszolút inzulinhiány kialakulását. ${ }^{8,9}$ Ez utóbbi felismerés eredményeként került ki a terápiás gyakorlatból frissen felismert T1DM-es személyek inzulinnal és SU-val együttes kezelése. ${ }^{10}$ Kétségtelen, hogy kis adag SU hozzáadása csökkenthette a napi inzulinszükségletet, ám gyorsíthatta az inzulinhiány teljessé válását. (Igen érdekes, hogy azzal a szulfanilureával, a gliclaziddal amely „perifériás” hatására ma a legtöbb megfigyeléssel rendelkezünk, nem történtek ilyen vizsgálatok. Ennek a készítmény ez idő tájt korlátozottabb használata, valamint az adatok később ismertté válása lehet a magyarázata.) A SU-knál később terápiás eszköztárba került meglitinid-származékok e célú alkalmazásával nem ismertek próbálkozások.

Ugyancsak történeti érdekességű az akarbóz T1DM-ben való adása. Kétségtelen, hogy a táplálékkal elfogyasztott szénhidrátok felszívódásának részleges gátlásával elérhető volt a pp. vércukor-emelkedések mérséklése, a gyakori gasztrointesztinális mellékhatások - elsősorban a fokozott flatulencia - azonban 
a mindennapi élet komfortjának csökkentésével e kombináció jelentős gátját képezték. Noha későbbi megfigyelések az alfa-glükozidáz-gátlók számos előnyét - endothelvédelem, vérzsírértékek javulása, kardiovaszkuláris kockázatcsökkentés - igazolták, az analóg prandiális inzulinok megjelenése, korábbi hatáskezdete és hatáscsúcsa indokolatlanná tette e kezelésforma megtartását T1DM-ben. ${ }^{11} \mathrm{Ez}$ az alkalmazási lehetőség a hatályos törzskönyvi előiratban sem szerepel.

\section{Nálunk is forgalmazott, nem- inzulintermészetű antidiabetikumok T1DM-ben}

A nálunk is forgalmazott, nem-inzulintermészetű vércukorcsökkentők közül a metformin, a GLP-1RA-k és az SGLT-2-gátlók alkalmazása jöhet szóba inzulin kiegészítéseként T1DM-ben. Megfigyelések ismertek DPP-4-gátlók inzulinhoz történő adásával is, eredményességük azonban elmaradt az előző kombinációkétól.

\section{Metformin}

Elsődleges hatása a - hepatikus és az egésztest- - inzulinrezisztencia (IR) mérséklése, másodlagosan a GLP-1 serkentése útján fokozza az inzulinszekréciót is (ennek T1DM-ben nincs klinikai relevanciája). Gátolja a glukagon release-t - ez T1DM-ben különösen előnyös, s a hepatikus IR mérséklődésének egyik összetevője -, a lipogén enzimek expresszióját, fokozza a zsírsav-oxidációt és a bélbaktériumok rövid láncú zsírsav termelését. Mérsékli az étvágyat, elősegíti a testsúly csökkenését. ${ }^{12}$ IR- és testsúlycsökkentő hatása révén mérsékelheti a napi inzulinszükségletet. Ez utóbbi egyes megfigyelések szerint független a testsúlycsökkenés mértékétől (és inkább az inzulinhatás javulásával magyarázható). ${ }^{13}$

Adása súlyfelesleggel rendelkező T1DM-es személyeknél, illetve az ún. double diabetes eseteiben ${ }^{14}$ törzskönyvön kívüli indikációként megengedett. A testsúly csökkentése mellett mérsékelheti a napi inzulinszükségletet, az össz-, az LDL-koleszterin-, valamint a trigliceridszintet (bár ezek emelkedése T1DM-ben kevéssé kifejezett). Az alkalmazását kísérő potenciális mellékhatások, valamint adása óvatossági előírásai a T2DM-ben ismerttel egyezőek. T1DM-ben azonban kiemelt jelentőségű a megfelelő (legalább napi 100 grammnyi) szénhidrát bevitele, a máj- és veseműködés követése, az acidogén kockázat figyelembevétele.
GLP-1-RA-k

Az inkretinek e csoportja farmakológiai GLP-1-hatás kiváltásával vércukorfüggő módon serkenti az inzulinelválasztást, gátolja a glukagonkibocsátást, származékai hatástartamuk függvényében erőteljesebben (rövid hatású származékok) vagy mérsékeltebben (hosszú és ultrahosszú hatású változatok) lassítják a gyomorürülést. Receptorok direkt serkentésével csökkentik a hepatikus IR-t. Központi idegrendszeri receptorok útján mérséklik az érvágyat, elősegítik a testsúly csökkenését. Javítják a vérzsírtükröt és kismértékben csökkentik a vérnyomást. A hosszú (liraglutid) és ultrahosszú változatok (dula-, semaglutid) cardio- és renoprotectiv természetét T2DM-ben prospektív vizsgálatok igazolták. Adásukat kezdeti gasztrointesztinális mellékhatások (nausea, teltségérzet, vomitus) kísérhetik, amelyek rövid idejűek és kis kezdőadagokkal jórészt elkerülhetők. A hosszú és ultrahosszú változatok esetében előfordulhat a passage lassulása (és gyorsulása) is, amire előre fel kell hívni az érintettek figyelmét.

Számos kedvező adat ismert T1DM-ben történő eredményes alkalmazásukról. A liraglutiddal folytatott 52 hetes ADJUNCT ONE, ${ }^{15}$ illetve 26 hetes AJUNCT $\mathrm{TWO}^{16} 3$ a fázisbesorolású vizsgálat után több kisebb esetszámú és rövidebb követési idejü megfigyelést is folytattak. Egy 11, GAD- és Cpeptid-pozitív kaukazoid személyt magába foglaló, $12 \pm 1$ hetes, prospektív vizsgálatban pl. azt találták, hogy azon személyek szérum-C-peptid-értéke, akik jól tolerálták a lira-, illetve dulaglutid alkalmazását, e rövid idő alatt is több mint háromszorosára emelkedett, az anyagcserekontroll javult, miközben az inzulinszükséglet közel $60 \%$-kal csökkent. (A vizsgálatba vontak diabetesének ismert tartama $6 \pm 2$ év volt. ${ }^{17}$ ) Több munkacsoport hasonlóan kedvező eredményt talált C-peptid-negatív T1DM-es személyek esetében is. ${ }^{18}$

Egy 7, egyenként legalább 8 hetes intervenciót tartalmazó, randomizált-kontrollált, paralel csoportos tanulmány adatait magába foglaló metaanalízis GLP-1-RA és inzulin együttes hatását elemezte inzulin önmagában történő adagolásával szemben. Azt találta, hogy a $\mathrm{HbA}_{1 c}$-érték -0,21\%kal (95\%-os konfidenciaintervallum [CI]: -0,41 $+0,02 ; p=0,03)$ kedvezőbben változott a kombinált kezelést kapó csoportban. A testsúlyváltozás hasonló összevetésben $-3,53 \mathrm{~kg}$ (95\%-os CI: $-4,56$ $-+2,19 ; \mathrm{p}<0,05)$ volt. A testsúlyra igazított napi össz-inzulindózis értékelhetően nem különbözött, 
a bólus inzulinadag azonban -0,06 E (95\%-os CI: $-0,1-+0,02 ; p=0,03)$ értékben változott. ${ }^{19}$

A dulaglutid alkalmazásával folytatott DIAMOND (Dulaglutide and Insulin MicrosecretiON in type 1 diabetes) vizsgálat jelenleg folyamatban van, esetközlések inzulin kiegészítéseként adagolt semaglutid T1DM-ben történő eredményes alkalmazásáról is ismertek. ${ }^{20}$

Bár nagyobb esetszámú és hosszabb követési idejü, randomizált vizsgálatok még váratnak magukra, a jelenlegi ismeretek alapján a GLP-1-RA-k a T1DM ígéretes adjuváns kezelési lehetőségét jelenthetik. Mindazonáltal, a hatályos törzskönyvi előiratok adásuk javallataként a T2DM-et említik, a T1DM ez idő szerint off label jelzéssel sem szerepel.

\section{DPP-4-gátlók}

Az inkretin hatásmechanizmusú szerek e másik csoportja az élettanilag termelődő polipeptidek, közöttük a GLP-1 és GIP inaktiválását végző DPP-4 enzim reverzibilis gátlásával segítik e hormonok hatásának megnyújtását, az inzulintermelés következményes vércukorfüggő fokozódását. (Mivel a GIP és a GLP-1 a glukagonkibocsátás tekintetében ellentétes hatású, e hormon szuppressziója a GLP-1-RA-kéhoz képest kevésbé érvényesül.) Az étvágyat és a gyomorürülést nem befolyásolják, testsúlyneutrális természetủek.

Bár inzulin kiegészítéseként adagolt sita-, illetve vildagliptinnel folytatott korábbi tanulmányok a $\mathrm{HbA}_{1 c^{-}}$ szint mérsékelt javulását és a pp. vércukorértékek csökkenését mutatták, a glükózvariabilitás és a napi inzulinszükséglet változása tekintetében ellentétes adatok születtek. Egy 5, egyenként 8-52 hetes újabb randomizált-prospektív vizsgálat adatait feldolgozó metaanalízis a DPP-4-gátló és inzulin kombináció alkalmazásával az inzulin-monoterápiához képest átalagosan -0,07\%-kal (95\%-os CI: -0,3 - -0,23) kedvezőbb csökkenést igazolt, de a különbség statisztikailag nem volt megerősíthető. Tendenciájában mérséklődtek a pp. vércukorértékek is. ${ }^{21}$

A két inkretin hatásmechanizmusú csoport T1DM-ben eltérő eredményességét nagyobb részben a GLP-1-hatás mértékének különbsége magyarázhatja (farmakológiai vs. élettani hatás), de abban a GIP GLP-1-gyel bizonyos mértékben ellentétes természete is közrejátszhat. A DPP-4-gátlók törzskönyvi előirata javallatként csak a T2DM-et említi.

\section{SGLT-2-gátlók}

E gyógyszercsoport, kémiai nevük közös utótagja alapján, a gliflozinok, a proximális vesetubulusban található nátrium-glükóz kotranszporter-2 szelektív gátlása és a renális glükózürítés következményes fokozása révén javítják a szénhidrát-anyagcserét. Az inzulintermelést közvetlenül nem befolyásolják, de a glüko- és lipotocixitás mérséklése révén csökkentik a béta-sejt-terhelést és erősítik a reziduális inzulintermelést. Alkalmazásuk során a glukagonkibocsátás kismértékben fokozódhat, az egésztest-IR ennek ellenére csökken. Adásuk során mérséklődik a testsúly, kismértékben csökken a vérnyomás, csökken az össz- és LDL-koleszterinszint. Az anyagcserét a ketontestképződés irányába tolják el, fokozzák a húgysavürülést, csökkentik az adipocitokinek közvetítette szöveti gyulladásos folyamatokat, az oxidatív stresszt és a vég-glikációs termékek képződését. ${ }^{22}$ Három képviselőjükkel - empa-, cana-, dapagliflozin - T2DM-ben folytatott prospektív vizsgálatok során igazolták a kardiovaszkuláris kompozit végpont (MACE: kardiovaszkuláris eredetű halálozás, nem fatális infarctus és nem fatális stroke) kontrollcsoportéhoz képest szignifikáns mértékű javulását és a szívelégtelenség miatti hospitalizáció ritkábbá válását. A szívelégtelenség előfordulásának csökkenése a többszörös keringési kockázati tényezővel rendelkező (de manifeszt keringési betegségtől mentes) betegcsoportban is kimutatható volt. Több származék esetében szignifikáns mértékben javult a veseműködés előre meghatározott kompozit végpontja is. Mellékhatásként genitális infekciók gyakoribbá válása fordulhat elő, nagyobb jelentőségű a ritka, de odafigyelést igénylő normoglykaemiás ketoacidosis (NKA) lehetősége.

Míg az előzőekben említett készítménycsoportok hatása közvetve vagy közvetlen támadásponttal, megtartott inzulintermelésen alapul - a T2DM tekintetében ez igaz a GLP-1-RA csoportra és az alfa-glükozidáz-gátlókra is -, az SGLT-2-gátlók vércukorcsökkentő természete független az inzulin jelenlététől. Ez a háttere adásuk legjelentősebb potenciális mellékhatásának, a már említett NKA-nak. ${ }^{23,24}$

Csak az analógia kedvéért említjük, hogy adásuk T2DM-ben is óvatosságot igényel közel normális tápláltsági állapotú személyek esetében, ahol a reziduális inzulinszekréció általában kisebb a túlsúllyal kísért esetekében megfigyeltnél.

Mind a dapa-, mind az empa-, cana- és sotagliflozinnal ismertek T1DM-ben inzulin kiegészítéseként történt alkalmazásukkal folytatott prospektív 
vizsgálatok. Egy 8, a felsorolt származékok mindegyikének vizsgálataira kitérő metaanalízisben azt találták, hogy a $\mathrm{HbA}_{1 \mathrm{c}}$-szint csökkenése 8-12 heti kezelés során volt a legkifejezettebb, de kisebb mértékben az 52 hetes vizsgálatok lezárásakor is igazolható volt. Mellékhatások - az NKA eseteit is beleértve - a kombinált kezelés során gyakrabban jelentkeztek a csak inzulint adagolókéhoz képest. ${ }^{25}$

A legrészletesebb vizsgálatokra (DEPICT $1^{26}$ és DEPICT $2^{27}$ ) dapagliflozin alkalmazásával került sor. E kettős vak, randomizált, multicentrikus, multinacionális, háromkarú, 3. fázisbesorolású tanulmányokat a készítmény 5, illetve 10 mg-os adagjának, valamint a harmadik karon placebónak inzulinnal történő kombinálásával végezték $\geq 27 \mathrm{~kg} / \mathrm{m}^{2}$ testtömegindexű személyeken.

A két vizsgálat felépítése azonos volt, a mindkettőben részt vevő centrumok mellett eltért a társországok/centrumok köre. Az előszűrést 8 hetes bevezető szakasz, majd 24 hetes kettős vak periódus, végül 28 héten át „vizsgálóhely-vak” időszak követte. Elsődleges végpontként a $\mathrm{HbA}_{1 \mathrm{c}}$-átlagérték 24. heti alakulását, másodlagos végpontként a testsúly, a glykaemiás célérték eléréséhez szükséges napi inzulinadag, a CGM-mel mért 24 órás vércukorátlag alakulását, a napszakos vércukorértékek céltartományon belüli arányát, továbbá a $>0,5 \%$-os $\mathrm{HbA}_{1 \mathrm{c}}$-csökkenést hypoglykaemiamentesen elérők csoportonkénti megoszlását elemezték, ugyancsak a 24. héten. A kiértékelést a vizsgálatok lezárásakor, az 52. héten is elvégezték. Azt találták, hogy az átlagos $\mathrm{HbA}_{1 \mathrm{c}}$-érték a placebo-karon lévőkéhez képest az aktív kezelési ágakon közel egyező mértékben, a DEPICT 1-ben $-0,42 \%$-kal csökkent $(\mathrm{p}<0,001)$, $\mathrm{s}$ a javulás kisebb mértékben $(-0,33$, illetve $-0,36 \%)$ a követés lezárásakor is megmaradt. (A DEPICT 2 eredményei a számértékek minimális eltérésével azonosnak bizonyultak.) Kismértékben csökkent az anyagcserekontroll eléréséhez szükséges napi inzulindózis, a glykaemiás variabilitás, a hypoglykaemiás epizódok napszakos aránya és nagyobb mértékben csökkent a testsúly is. ${ }^{26,27}$

A kedvező eredmények nyomán 2019 márciusában a dapagliflozin $5 \mathrm{mg}$-os változatát törzskönyvezték $\geq 27 \mathrm{~kg} / \mathrm{m}^{2}$ testtömegindexű T1DM-es személyek inzulinkezelésének kiegészítésére.

\section{Tiazolidindionok}

Vércukorcsökkentő hatásuk a PPAR-gamma-receptorok aktiválásán keresztül, a zsír- és izomszövet glükózfelvételét fokozó génexpresszió elősegítésével érvényesül. Mindkét származékuk, a rosi-, illetve pioglitazon a T2DM vércukorcsökkentő kezelésének eszköztárába tartozott. Mint ismert, Nissen és Wolski metaanalízisének megjelenését, majd annak más munkacsoportok által történő megerősítését követően a rosiglitazont az európai forgalmazásból visszavonták (az Egyesült Államokban jelentős korlátozásokkal forgalomban maradt). Inzulinnal történő együtt adása ellenjavallt. A glitazonok mellékhatásspektruma igen kedvező, érdemi panasz adásukat nem kíséri. Előnyösen befolyásolják a vérzsírértékeket. Adásuk hátránya viszont - a hatásmechanizmusukból eredő - zsírtömeg- (testsúly-) gyarapodás.

A pioglitazon törzskönyvében szerepel inzulinnal történő együttadásának lehetősége T2DM-ben, megfigyelések ismertek T1DM-ben inzulin kiegészítéseként történő eredményes alkalmazásáról is. ${ }^{28}$ A bíztató in vitro megfigyelések alapján fölvetett béta-sejt-prezerváló hatás újonnan felismert T1DM-es személyeken 24 hetes prospektív vizsgálatban nem volt megerősíthető. ${ }^{29}$ Pioglitazon-monoterápiás készítmény ez idő szerint hazánkban nincs forgalomban.

\section{Nálunk jelenleg nem forgalmazott, nem- inzulintermészetü antidiabetikumok adása T1DM-ben}

Egyetlen hatóanyag, az amylinanalóg pramlintid tartozik e körbe. Hármas támadásponttal - a jóllakottságérzet fokozásával, a gyomorürülés lassításával és a glukagonkibocsátás szupprimálásával - csökkenti - elsősorban a pp. - vércukorszintet. ${ }^{2}$ E hatásmechanizmus eredményeként mérséklődik a hepatikus glükózkibocsátás és elhúzódóbbá válik a táplálékkal elfogyasztott szénhidrát felszívódása. Következményesen csökken a testsúly is. Adása inzulinterápia kiegészítéseként T2- és az FDA 2005ben kiadott jóváhagyása alapján, bázisinzulinnal T1DM-ben is megengedett. Adagolása kezdetén hányinger, hányás fordulhat elő. ${ }^{30} \mathrm{Az}$ Egyesült Államokban legújabban vizsgálatok folynak a pramlintid inzulinnal (A21G) kombinált változatának T1DM-ben történő alkalmazásával. ${ }^{31}$

\section{Mit hoz(hat) a jövő?}

A T1DM inzulinkezelésének a bevezetőben fölvetett még megoldatlan részleteiben („unmet needs”) 
részben az inzulinkészítmények további szerkezeti és következményes hatásspektrumbeli - módosítása, részben az inzulinpumpa-kezelés eszköztárának bővülése jelenthet előrelépést. További lehetőségként említhető a már ma is alkalmazott kombinációk - elsősorban a GLP-1-RA-k, SGLT-2-gátlók és a pramlintid - szélesebb körű alkalmazása, a felgyülemlő tapasztalatok napi gyakorlatba építése, nem utolsósorban új terápiás lehetőségek csatasorba állítása. Ilyen utóbbi lehet, ha nem is a közeljövőben a gén- és sejtpótló terápia, ${ }^{32}$ vagy a glukagonreceptor elleni antitestek kifejlesztése.
Trodalom

1. Bowden SA: Partial remission (honeymoon phase) of type 1 diabetes mellitus. In: Frontiers in Clinical Drug Research-Diabetes and Obesity. Volume 6. D01: 10.2174/9781681084459117040004

2. Frandsen CS, Dejgaard TF, Madsbad S: Non-insulin drugs to treat hyperglycaemia in type 1 diabetes mellitus. Lancet Diabetol Endocrinol 2016; 4(9): 766-780. Dol: 10.1016/52213-8587(16)00039-5

3. Danne T, Nimri R, Battelino T, Bergenstal RM, Close $\mathrm{KL}$, DeVries JH, et al: International Consensus on Use of Continuous Glucose Monitoring. Diabetes Care 2017; 40(12): 1637-1640. D01: 10.2337/dc17-1600

4. Beck RW, Tamborlane VW, Bergenstal RM, Miller KM, DuBose SN, Hal CE for the 11 Clinic Network: The TID Exchange Clinic Registry. J Clin Endocrinol Metab 2012; 97: 4383-4389. Dol: 10.1210/jc.2012-1561

5. Garg V: Noninsulin pharmacological management of type 1 diabetes mellitus. Ind J Endocrinol Metab 2011; 15(Suppl. 1): S5-S11. D01: 10.4103/2230-8210.83053

6. Ballav C, Gough SCL: An overview of non-insulin adjunctive therapies for type 1 diabetes. Diabetes Manag 2014; 4(5): 1-16. D01: 10.2217/DMT.14.38

7. Lingow SE, Burke SD, Brooks AD, Rafferty PS: Role of noninsulin therapies in the treatment of type 1 diabetes. Spectrum Diabetes 2019; 32(2): 164-170. Dol: 10.2337/ds 18-0058

8. Kabadi VM: Adjuvant therapy with tolazamide and insulin improves metabolic control in type I diabetes mellitus. Diabetes Care 1985; 8(5): $440-446$. D01: $10.2337 /$ diacare. 8.5 .440

9. Stocks AE, Ma A, HowlettV, Cameron DP: Lack of effect of glibenclamide on insulin requirement and diabetes control in persons with insulin-dependent diabetes mellitus. Med J Austr 1988; 149(9): 472-473.

10. Fallucca F, Sciullo E, Maldonato A: Combined therapy with insulin and sulfonylurea for the treatment of new-onset insulin-dependent diabetes mellitus. Horm Metab Res 1996; 28(2): 86-88. D01: $10.1055 / 5-2007-979134$

11. DiNicolantonio IJ, Bhutans J, $0^{\prime}$ Keefe JH: Acarbose: safe and effective for lowering postprandial hyperglycaemia and improving cardiovascular outcome. BMJ Open Heart 2015; 2(1): 1-13. D01: 10.1136/openhrt-2015-000327

12. Winkler G: Miért a metformin (még mindig) a 2-es típusú diabétesz elsőként választandó vércukorcsökkentö gyógyszere? Háziorvos Továbbképzö Szemle 2017; 22(2): 120-124.
13. Beysel S, Unsal IU, Kizilgui M, Caliskan M, UIcan $B$, Cakai M: The effects of metformin in type 1 diabetes mellitus. BMC Endocrine Disorders 2018; 18(1): 1-6. DO1: 10.1186/512902-017-0228-9

14. Nádas J, Putz Zs, Fövényi I, Gaál Zs, Gyimesi A, Hidvégi T, et al: Cardiovascular risk factors characteristic for the metabolic syndrome in adult patients with type 1 diabetes. Exp Clin Endocrinol Diabetes 2008; 117: 107-112. D01: 10.1055/s-0028-1082068

15. Mathieu C, Zinman B, Hemmingsson JU, Woo V, Colman P, Christiansen E, et al for the ADJUNCT ONE investigators: Efficacy and Safety of Liraglutide Added to Insulin Treatment in Type 1 Diabetes: The ADJUNCT ONE Treat-To-Target Randomized Trial. Diabetes Care 2016; 39(10): 1702-1710. D01: 10.2337/dc16-0691

16. Ahrén B, Hirsch IB, Pieber TA, Mathieu C, Gómez-Peralta $F$, Hansen TK, et al for the ADJUNCT TWO randomized trial: Efficacy and safety of liraglutide added to capped insulin treatment in subjects with type 1 diabetes. The ADJUNCT TWO randomized trial. Diabetes Care 2016; 39(10): 1693-1701. D01: 10.2337/dc16-0690

17. Kuhadiya ND, Prohaska $B$, Ghanim $H$, Dandona P: Addition of GLP-1 therapy to insulin in C-peptidepositive patients with type 1 diabetes. Diabetes 2018 ; 67(Suppl. 1): 1054-1057. D01: 10.2337/db18-110-LB

18. Crisci I, Aragona M, Politi KS, Daniele G, DelPrato S: GLP-1-receptoragonists in type 1 diabetes: a proof-of-concept approach. Acta Diabetol 2015; 52: 1129-1133. D01: 10.1007//500592-015-0800-6

19. Wang W, Liu H, Xiao S, Liu S, Li X, Yu P: Effects of insulin plus glucagon-lipe peptide-1 receptor agonists (GLP-1 RA-s) in treating type 1 diabetes: a systematic review and meta-analysis. Diabetes Ther 2017; 8: 727-738. D01: 10.1007//33300-017-0282-3

20. Sofra D, Beer S: Impact of adding semaglutide in a person with type 1 diabetes. A case report. Diabetes Updates 2019; 5: 1-4. D01: 10.15761/DU.1000128

21. Wang 0 , Long $M$, Qu H, Shen $R$, Zhang $R$, Xu J, et al.: DPP-4 inhibitors as treatment for type 1 diabetes mellitus: a systematic review and meta-analysis. J Diab Res 2018; 5308582. D01: 10.1155/2018/5308582

22. Cowie MR, Fisher M: SGLT2 inhibitors: mechanisms of cardiovascular bvenefits beyond glycemic control. Nature Rev Cardiol 2020; 17 (12): 761-772. D01: $10.1038 / 541569-020-0406-8$

23. Simes BC, MacGregor GG: Sodium-glucose cotransporter-2 inhibitors: a clinician's guide. Diabetes Metab Syndr Obes 2019; 12: 2125-2136. D01: 10.214710MS0.5212003
24. Peter AL, Buschur EO, Buse JB, Cohan P, Diner JC, Hirsch IB: Euglycemic diabetic ketoacidosis: a potential complication of treastment with sopdfiumglucose cotransporter 2 inhibition. Diabetes Care 2015; 38(9): 1687-1693. D01: 10.2337/dc15-0843

25. Taylor SI, Blau JM, Rother KJ, Beitelshees AL: SGLT2 inhibitors as adjunctive therapy for type 1 diabetes: balanc ing benefits and risks. Lancet Diabetes Endocrinol 2019; 7(12): 949-958. Dol: 10.1016/52213-8587(19)30154-8

26. Dandona P, Mathieu C, Philip S, Hansen L, Griffen SC, Ischöpe D, et al., the DEPICT1 investigators: Efficacy and safety of dapagliflozin in patients with inadequately controlled type 1 diabetes (DEPICT 1): 24 week results from a multicentre, double-blind, phase 3, randomized trial. Lancet Diabetes Endocrinol 2017; 5(11): 864-876. Erratum: Lancet Diabetes Endocrinol 2017; 5(12): e8. Dol: 10.1016/52213-8587(177)30375-3

27. Mathieu C, Dandona P, Gillard PO, Senior $P$, Hasslacher C, Araki E, et al. on behalf of the DEPICT 2 investigators: Efficacy and safety of dapagliflozin in patients with inadequately controlled type 1 diabetes (DEPICT 2): 24 week results from a randomized trial. Diabetes Care 2018; 41(9): 1938-1946. D0I: 10.2337/dc18-0623

28. Bhat R, Bhansali A, Bhadada S, Sichy R: Effect of pioglitazone therapy in lean type 1 diabetes mellitus. Diab Res Clin Pract 2007; 78(3): 349-354. D0I: 10.1016/i.diabres.2007.04.012

29. Tafuri KS, Godil MA, Lane AH, Wilson TA: Effect of piuoglitazone on the course of new-onset type 1 diabetes mellitus. I Clin Res Pediatr Endocrinol 2013; 5(4): 236-239. D01: 10.4274/Jcrpe. .881

30. Edelmann SV, Darsow T, Friss JP: Pramlintide in the management of insulin-using patients with type 2 and type 1 diabetes. Vasc Health Risk Manag 2006; 2(3): 203-212. D01: 10.2147/vhrm. 2006.2.3.203

31. Meiffren G, Andersen G, Eloy R, Seroussi C, Mégret C, Famulla S, et al: : 112-LB: AD009, a coformulation of pramlintide (PRAM) and insulin A21G, improves postprandial glucose vs. Novolog in type 1 diabetes (T1D). Diabetes 2020; 69(Suppl. 1): meeting abstract (ADA) https://doi.org/10.2337/db20-112-LB

32. Halban PA, Kahn SE, Lenmark A, Rhodes (J: Gene- and cell-replacement therapy in the treatment of type 1 diabetes. How high must the standards be set? Diabetes 2001; $50(10)$ : 2181-2191. D01: 10.2337/diabetes.50.10.2181 